\title{
Persistence of Viral Antibodies in Patients with Chronic Bronchitis
}

\author{
MARGARET A. J. MOFFAT,* B.SC., PH.D. ; J. A. W. SUTHERLAND, † F.I.M.L.T.
}

Brit. med. F., 1967, 1, 601-603

An acute exacerbation of bronchitis is preceded sometimes by a common cold or influenza-like illness, and for this reason viruses have been incriminated as the initiating factor in such attacks. During the past 10 years many workers have attempted to elucidate the role of viruses in exacerbations of chronic bronchitis, but the results have been contradictory and attempts to isolate a virus have been particularly disappointing. In a survey carried out by Murdoch, Leckie, Downie, Swain, and Gould (1959) on outpatients in Edinburgh, 14 out of 31 patients showed a rise in complement-fixing antibodies to either influenza $\mathrm{A}, \mathrm{B}$, or $\mathrm{C}$ or adenovirus, but only three of these rises could be associated with clinical infection. Jack and Gandevia (1960) reported completely negative virological findings in 19 patients during one year. Stark, Heath, and Curwen (1965) examined sera from outpatients in London at four-week intervals : 23 out of 199 patients showed evidence of viral infection, and in 13 this could be correlated with an exacerbation. A more comprehensive study was carried out by Carilli, Gohd, and Gordon (1964) in Boston: 46 cases of respiratory illness occurred, and 23 of these could be associated with viral infections ; respiratory syncytial virus alone appeared to be responsible for $17 \%$, but no common-cold viruses were isolated. Sommerville (1963) has also shown a high incidence of antibodies to respiratory syncytial virus in sera from chronic bronchitics in Glasgow. More recent studies in the Glasgow area showed $16 \%$ of exacerbations to be associated with rising titres to various respiratory viruses (Ross, McMichael, Eadie, Lees, Murray, and Pinkerton, 1967).

The patients included in the present survey had been included in the Medical Research Council Early Bronchitis Trial, and the clinical and bacteriological findings will be published separately (Calder and Schonell, 1967). Sera have been taken from these men at approximately eight-week intervals since December 1961 and have been tested for complement-fixing antibodies to the respiratory viruses to detect evidence of infection. The survey also provided the opportunity to study the length of time for which antibody titres persist in patients with chronic bronchitis.

\section{Materials and Methods}

Clinical Material.-Cases were selected for the Medical Research Council trial by fulfilling the following criteria: (1) patients should be males aged 40-59 at the time of admission to the trial ; (2) they should have had at least two illnesses characterized by the production of increased sputum in the three years before the date of admission, causing them to be off work for a total of at least three weeks ; (3) they should have had a productive cough (not only on rising) for at least three months in each of the past two years ; $(4)$ the indirect maximum breathing capacity must be greater than $50 \mathrm{l} . / \mathrm{min}$. (equivalent 1-second F.E.V., 1.40 1.). The men were examined clinically every eight weeks, and at the same time blood was collected for virological studies.

Laboratory Procedures.-Complement-fixation tests were carried out according to the technique described by Bradstreet and Taylor (1962). The sera were tested against the following antigens: influenza $\mathrm{A}, \mathrm{B}$, and $\mathrm{C}$, Sendai, parainfluenza 1, 2,

* Virologist, Wellcome Laboratory, City Hospital, Edinburgh

t Senior Technician, Wellcome Laboratory, City Hospital, Edinburgh. and 3, adenovirus, psittacosis, Coxiella burnetii, mumps $S$ and $\mathrm{V}$, respiratory syncytial virus. Most complement-fixation reagents were obtained from the Standards Laboratory for Serological Reagents, Central Public Health Laboratory, Colindale, London. Parainfluenza 1 antigen was originally obtained from Colindale but later from Burroughs Wellcome. Parainfluenza 2 and 3 antigens were obtained from Microbiological Associates. Respiratory syncytial antigen was prepared in this laboratory from the Randall strain but more recently this was obtained from Colindale. Sera from the same patient were tested separately when they were received; if any change in the titre was noted the serum was retested in parallel with the previous specimen. Sera were also examined for cold agglutinins to human group $\mathrm{O}$ erythrocytes.

\section{Results}

Twenty-five patients were originally included in the investigation ; five of these were not examined for more than six months, so the present analysis is limited to the 20 whose sera were investigated at regular intervals for more than four years. During this time 68 exacerbations of bronchitis were experienced by these patients.

The complement-fixing antibody titres and the number of exacerbations of bronchitis for each patient are shown in Table I. Only the titres of the first and last specimens of serum are shown; where there is no asterisk there has been no more than a twofold rise or fall between individual sera during the whole period of study. There were no antibodies to $C$. burnetii, and all tests for cold agglutinins were negative.

Evidence of viral infection indicated by a fourfold or greater rise in antibody titre was found in six patients (shown in Table I by an asterisk). These positive results are shown in more detail in Table II, where it may be seen that three of these rises could be related to an exacerbation of bronchitis and one was associated with a prolonged cold. It can thus be calculated that $3(4.4 \%)$ of the total of 68 exacerbations could be associated with viral infections. Though sputum was collected for bacteriological investigations at all routine visits, the examination of exacerbation specimens was not started until October 1962. As can be seen from Table II, only one patient (Case 14) had a viral infection associated with an exacerbation after this time; Proteus was isolated on this occasion.

It was of particular interest to note the considerable length of time for which complement-fixing antibodies could persist in the serum at high levels. Three patients (Cases 1, 2, and 17) who showed no evidence of recent infection with influenza $A$ had titres of 128 or greater throughout the four years of study (Table I). One patient (Case 20) who had a fourfold rise to influenza A in April 1962 still had a titre of 256 eight months later (Table II). The titre then fell to a level of 128 and remain unchanged for the next three years. This patient showed a concurrent rise to influenza $B$, which remained at a titre of 64 or greater for eight months. Antibodies to influenza $\mathrm{C}$ remained at high levels, as shown by Case 3, who had a titre of 128 throughout the survey (Table I). There was no evidence - of recent infection with parainfluenza virus in any of the patients but a persistent titre of 64 was not uncommon (see Case 1). Antibodies to adenovirus likewise persisted, and in Case 13 (Table II), who showed serological evidence of recent 
infection, a titre of 128 was present for 10 months Respiratory syncytial virus antibodies were found in several patients, and one (Case 11) who had evidence of infection gave a titre of 64 for six months (Table II).

From these results it is evident that complement-fixing antibodies may persist at high levels for a considerable time and that such titres are not necessarily indicative of recent infection. These titres varied with different antigens and are as follows: influenza A (256), influenza B (64), influenza C (128), Sendai (64), parainfluenza (64), adenovirus (128), respiratory syncytial (64).

\section{Discussion}

Though four out of the six viral infections diagnosed in this investigation could be related to clinical findings, only a small proportion $(4.4 \%)$ of the total exacerbations could be attributed in any way to viruses. Jack and Gandevia (1960) reported completely negative results but suggested that viruses not then identifiable might play a part in some exacerbations of chronic bronchitis. Since then it has become possible to isolate the rhinovirus group, but Carilli et al. (1964), using suitable cultural conditions for this group of viruses, failed to isolate these agents; their survey covered a period of only eight months, and their negative findings may have been due to the prevalent strain being particularly difficult to isolate (Tyrell and Bynoe, 1966). Some work in Glasgow (Eadie, Scott, and Grist, 1966) has provided evidence that the rhinoviruses may indeed play a part in chronic bronchitis. It would

TABLB II.-Persistence of C.F. Antibodies Following a Viral Infection in Sera from Patients with Chronic Bronchitis

\begin{tabular}{|c|c|c|c|c|c|c|c|c|c|}
\hline \multirow{2}{*}{$\begin{array}{l}\text { Case } \\
\text { No. } \\
3\end{array}$} & \multirow{2}{*}{$\begin{array}{l}\text { Antigen } \\
\text { Adeno }\{\end{array}$} & \multicolumn{7}{|c|}{$\begin{array}{l}\text { Serum Dates } \\
\text { Reciprocal of C.F. Antibody Titre }\end{array}$} & \multirow{2}{*}{$\begin{array}{l}\begin{array}{c}\text { Associated } \\
\text { Clinical } \\
\text { Symptoms }\end{array} \\
\text { None }\end{array}$} \\
\hline & & $\begin{array}{c}1 / 62 \\
16\end{array}$ & $\begin{array}{r}3 / 62 \\
512\end{array}$ & $\begin{array}{r}4 / 62 \\
256\end{array}$ & $\begin{array}{r}6 / 62 \\
128\end{array}$ & $\begin{array}{r}9 / 62 \\
64\end{array}$ & $\begin{array}{l}1 / 66 \\
* 64\end{array}$ & & \\
\hline 11 & RS & $\begin{array}{l}1 / 63 \\
<16\end{array}$ & $\begin{array}{r}3 / 63 \\
128\end{array}$ & $5 / 634^{\circ}$ & $\begin{array}{r}7 j 63 \\
.32\end{array}$ & $\begin{array}{r}9 / 63 \\
64\end{array}$ & $\begin{array}{r}11 / 63 \\
16\end{array}$ & $1 / 66$ & " \\
\hline 12 & Influ- $C\{$ & $\begin{array}{r}3 / 62 \\
32\end{array}$ & $\begin{array}{l}5 / 62 \\
>512\end{array}$ & $\begin{array}{l}7 / 62 \\
>512 \\
\end{array}$ & $\begin{array}{r}9 / 62 \\
.256\end{array}$ & $\begin{array}{r}11 / 62 \\
128\end{array}$ & $\begin{array}{r}4 / 63 \\
64 \\
\end{array}$ & $\begin{array}{r}1 / 66 \\
* 64\end{array}$ & $\begin{array}{c}\text { Exacerbation } \\
\text { April } 1962\end{array}$ \\
\hline 13 & Adeno \{ & $\begin{array}{r}2 / 62 \\
32\end{array}$ & $\begin{array}{r}5 / 62 \\
128\end{array}$ & $\begin{array}{r}9 / 62 \\
128\end{array}$ & $\begin{array}{r}11 / 62 \\
128\end{array}$ & $\begin{array}{r}1 / 63 \\
128\end{array}$ & $\begin{array}{r}2 / 64 \\
128\end{array}$ & $\begin{array}{r}7 / 65 \\
* 64\end{array}$ & $\begin{array}{l}\text { Prolonged } \\
\text { cold } \\
\text { March } 1962\end{array}$ \\
\hline 20 & $\begin{array}{c}\text { Influ- } \\
\text { enza A } \\
\text { Influ- } \\
\text { enza B }\end{array}$ & $\begin{array}{r}2 / 62 \\
256 \\
<16\end{array}$ & $\begin{array}{l}4 / 62 \\
1024 \\
1024\end{array}$ & $\begin{array}{r}6 / 62 \\
256 \\
128\end{array}$ & $\begin{array}{r}9 / 62 \\
256 \\
64\end{array}$ & $\begin{array}{r}12 / 62 \\
256 \\
64\end{array}$ & $\begin{array}{r}2 / 63 \\
128 \\
32\end{array}$ & $\begin{array}{l}1 / 66 \\
128 \\
* 32\end{array}$ & $\begin{array}{r}\text { Exacerbation } \\
\text { March } 1962\end{array}$ \\
\hline 14 & $\underset{\text { enza }}{\text { Influ- }}\{$ & $\begin{array}{r}1 / 66 \\
16\end{array}$ & $\begin{array}{l}2 / 66 \\
1024\end{array}$ & $\begin{array}{r}3 / 66 \\
512\end{array}$ & $\begin{array}{r}4 / 66 \\
256\end{array}$ & $\begin{array}{r}8 / 66 \\
+256\end{array}$ & & & $\begin{array}{l}\text { Exacerbation } \\
\text { January } \\
1966\end{array}$ \\
\hline
\end{tabular}

- No more than a twofold rise or fall between individual sera during the period indicated.

TABle I.-Complement-fixing Antibody Titres to the Respiratory Viruses in Sera from Patients with Chronic Bronchitis

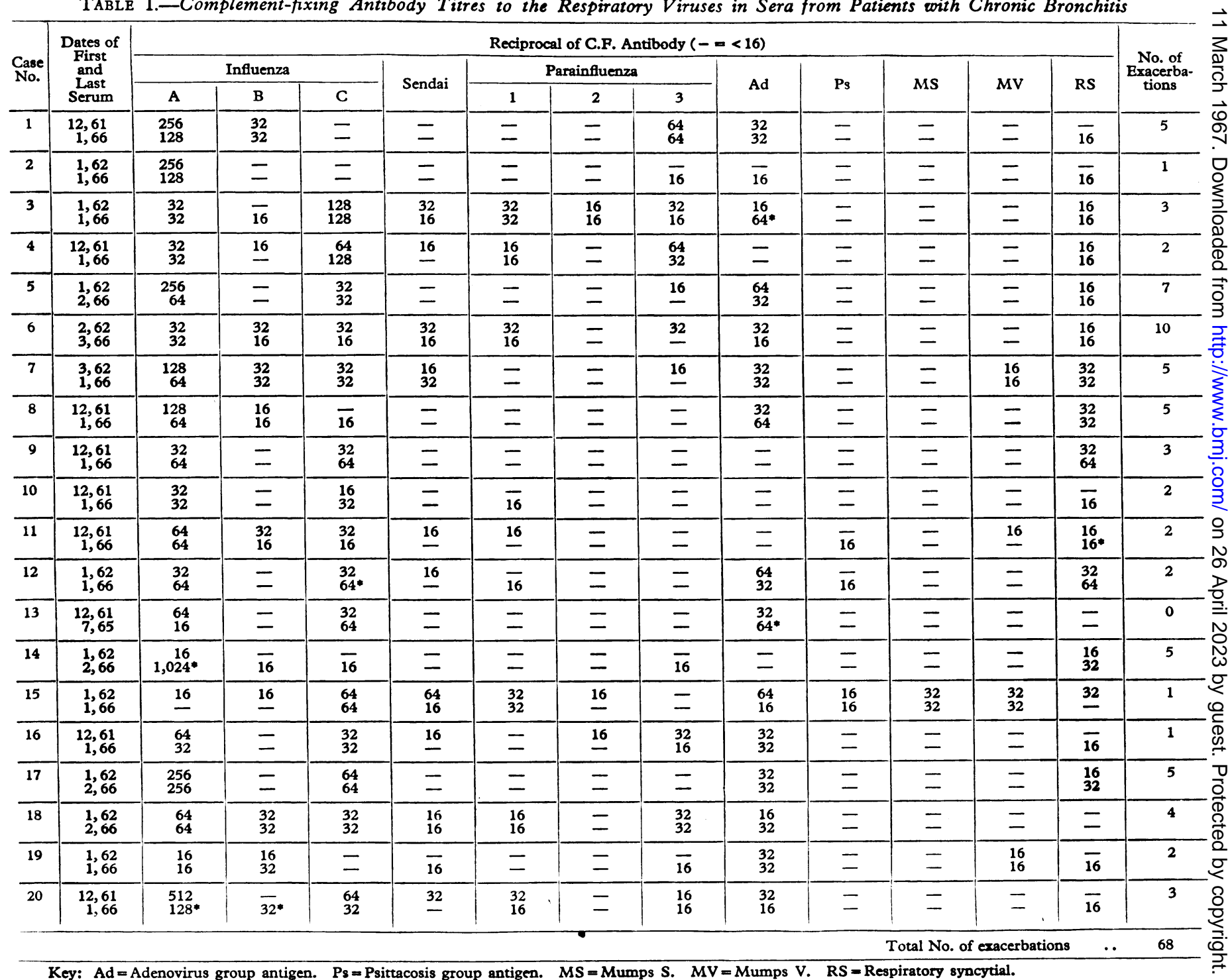

Key: $\mathrm{Ad}=$ Adenovirus group antigen. Ps = Psittacosis group antigen. MS = Mumps S. MV=Mumps V. RS = Respiratory syncytial.

- Indicates evidence of viral infection as demonstrated by a fourfold or greater rise in antibody titre at some stage during the survey. Where there is no asterisk there has been no more than a twofold rise or fall between individual sera during the period indicated. 
seem essential, therefore, that any future investigations into the aetiology of chronic bronchitis should include an intensive search for rhinoviruses along with the more routine virological and bacteriological methods.

It is widely accepted that a fourfold or greater rise in antibody titre indicates viral infection, and for this reason virologists are continually stressing the importance of sending paired sera to the laboratory to demonstrate such a rise. The importance of this practice would seem to be supported strongly by our present results, which show that certain viral antibody titres may remain at high levels for several years. This finding does not appear to be restricted to chronic bronchitics, as a recent paper from Glasgow shows similar findings in cases and matched controls (Ross et al., 1967). This persistence of antibodies in individuals over 40 years of age may be due to repeated previous infection, but this does not alter the fact that a single sample of blood sent from such a patient would be of negligible diagnostic value. On the other hand, antibody titres above the persistent levels quoted in this paper may be significant. These levels may hold true only for this laboratory, but it should be possible for each laboratory to find such a level which would be of some help to the clinician anxious to establish a diagnosis on a single sample of serum.

\section{Summary}

Sera from 20 patients with chronic bronchitis have been examined for viral complement-fixing antibodies over a period of four years. During this time 68 exacerbations occurred, but only $3(4.4 \%)$ of them could be related to viral infection.
Elevated antibody titres were found to persist over a long period of time and the significance of this finding is discussed.

We would particularly acknowledge the co-operation of the patients involved in this study. We would also thank the clinicians: Professor J. W. Crofton, Dr. H. M. McLeod, Dr. D. O. Lewis, Dr. M. E. Schonell, Dr. E. Ruth Gray, Dr. C. F. Spiers, Dr. J. Turnbull, Dr. J. D. Bell, and Dr. C. J. D. Aitken; and the health visitors: Mrs. J. T. Murray, Miss M. Graham, and Miss H. Mitchell. Mrs. M. Robertson gave invaluable secretarial assistance in the co-ordination of the trial. The bacteriological investigations were carried out by Dr. Margaret Calder. We are grateful to Professor Crofton for his continued encouragement and advice, to Professor R. Cruickshank, Dr. R. H. A. Swain, Dr. A. T. Wallace, Dr. Constance A. C. Ross, Dr. M. E. Schonell, and Dr. W. Gray for helpful criticism ; to Dr. G. E. D. Urquhart, Mrs. Hazel Cross, Mr. H. W. Moncrieff, Mr. R. S. Anderson, and Mr. T. Johnston for technical assistance ; and to Miss $M$. White for secretarial assistance. The Wellcome Trust and the Scottish Hospitals Endowment Research Trust provided generous grants.

\section{RBPERENCBS}

Bradstreet, C. M. P., and Taylor, C. E. D. (1962). Mth. Bull. Minist. Hlth Lab. Servo, 21, 96.

Calder, M. A., and Schonell, M. E. (1967). To be published.

Carilli, A. D., Gohd, R. S., and Gordon, W. (1964). New Engl. 7. Med., $270,123$.

Eadie, M. B., Stott, E. J., and Grist, N. R. (1966). Brit. med. 7., 2, 671.

Jack, I., and Gandevia, B. (1960). Amer. Rev. resp. Dis., 82, 482.

Murdoch, J. McC., Leckie, W. J. H., Downie, J., Swain, R. H. A., and Gould, J. C. (1959). Brit. med. F., 2, 1277.

Ross, C. A. C., McMichael, S., Eadie, M. B., Lees, A. W., Murray, B. A., and Pinkerton, I. (1967). Thorax. In press.

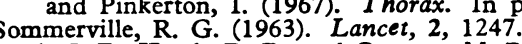

Stark, J. E., Heath, R. B., and Curwen, M. P. (1965). Thorax, 20, 124.

Tyrrell, D. A. J., and Bynoe, M. L. (1966). Lancet, 1, 76.

\title{
Trial of Ascorbic Acid in Prevention of Colds
}

\author{
GEORGINA H. WALKER,* M.B., CH.B.; M. L. BYNOE,* M.B., D.T.M.\&H. ; D. A. J. TYRRELL,* M.D., F.R.C.P.
}

Ascorbic acid is widely used as a prophylactic and therapeutic agent against the common cold, and is in fact often recommended for this purpose by medical practitioners. It may be administered as a large dose as soon as possible after the first symptoms are felt, and this dosage is then continued for a few days in order to "abort" the cold. Though many people use this treatment on themselves and believe it is effective, it is impossible to assess its efficacy. Untreated subjects may experience symptoms such as sneezing or a mild sore throat, which then disappear without going on to a full cold, and patients' assessments of their colds are much influenced by any treatment owing to the placebo effect (Diehl et al., 1938).

In these studies we attempted to show by in-vitro experiments that exposure of cells to ascorbic acid increased their resistance to infection with viruses. Though there was no activity in vitro, we also attempted to demonstrate a protective effect in animals or man, since it was thought that host resistance might be enhanced indirectly.

\section{Materials and Methods}

Virus Strains.-Strains of viruses selected from the biological groups known to cause common colds and related diseases were used (see Table I).

- From the Common Cold Research Unit, Salisbury, Wilts.
Tissue Cultures.-Roller-tube cultures were used, as follows: (1) "Diploid" human embryo lung fibroblast cells (HEL). A semicontinuous line isolated in this laboratory was used and maintained in Eagle's medium with $2 \%$ ox serum and antibiotics. (2) Monkey kidney cells (MK) ; cultures of secondary trypsinized cells were washed three times and maintained in Eagle's medium. (3) Hela cells of the Bristol line were maintained in $2 \%$ rabbit serum in Eagle's medium.

Ascorbic Acid.-Ascorbic acid for injection was added to tissue culture medium immediately before use. Preliminary experiments showed that $10 \mathrm{mg}$. of ascorbic acid/100 ml. of medium was not toxic in HEL, HeLa, or MK cells, and there was no crystal deposition. This concentration was therefore

TaBLB I.-Viruses Used in Tissue-culture Experiments with Ascorbic

\begin{tabular}{|c|c|c|c|c|}
\hline Family & & Group & Strain & $\begin{array}{l}\text { Tissue Used for } \\
\text { Propagation }\end{array}$ \\
\hline $\begin{array}{l}\text { Picornavirus } \\
\text { \#" } \\
\text { Myxovirus } \\
\text { ”, } \\
\text { Adenovirus } \\
\text { Enterovirus } \\
\text { " } \\
\text { Herpesvirus }\end{array}$ & $\begin{array}{l}\because \\
\because \\
\because \\
\because \\
\because \\
\because \\
\because\end{array}$ & $\begin{array}{l}\text { Rhinovirus H } \\
\text { „” H } \\
\text { Influenza B } \\
\text { Parainfluenza } 3 \\
\text { Respiratory syncytial } \\
\text { Adenovirus } 5 \\
\text { Poliovirus 1 } \\
\text { E.C.H.O. 11 } \\
\text { Coxsackie A21 } \\
\text { Herpes simplex }\end{array}$ & $\begin{array}{l}16 / 60 \\
\text { FEB } \\
\text { HGP } \\
\text { B Eng/101/62 } \\
\text { Prototype } \\
\text { Randall } \\
\text { Prototype } \\
\text { LSc 2ab } \\
\text { U virus } \\
\text { Local strain } \\
\text { Perrett* }\end{array}$ & 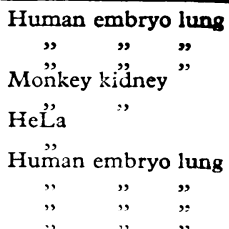 \\
\hline
\end{tabular}

